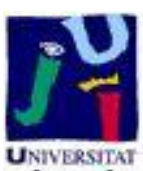

Título artículo / Títol article: Teachability and bilingualism effects on third language learners' pragmatic knowledge

Autores / Autors Eva Alcón Soler

Revista:

Intercultural Pragmatics (2012), vol. 9, num. 4

Versión / Versió:

Preprint del autor

Cita bibliográfica / Cita bibliogràfica (ISO 690):

url Repositori UJI:
ALCÓN SOLER, Eva. Teachability and bilingualism effects on third language learners' pragmatic knowledge. Intercultural Pragmatics, 2012, vol. 9, no 4, p. 511-541.

http://hdl.handle.net/10234/72284 


\section{Teachability and bilingualism effects on third language learners' pragmatic knowledge}

Eva Alcón Soler

Universitat Jaume I

Castellón (Spain)

Email: alcon@ang.uji.es

Eva Alcón Soler is Full Professor of English Language and Linguistics at the Universitat Jaume I (Castellón, Spain) and leader of the Research Group Applied Linguistics to English Language Teaching. She holds a BA in English Philology and an $\mathrm{MA}$ and a PhD in Applied Linguistics from the University of Valencia. Her research interests include learners' acquisition of L2 pragmatics, the role of interaction in L2 learning, and multilingualism. She has published widely on these issues in international journals such as Communication and Cognition, International Review of Applied Linguistics, System, among others). She is the author of Bases Lingüísticas $y$ Metodológicas para la Enseñanza de la Lengua Inglesa (2002) and has edited Learning How to Request in an Instructed Language Learning Context (Peter Lang, 2008). She has also co-edited Intercultural Language Use and Language Learning (Springer, 2007) and Investigating Pragmatics in Foreign Language Learning, Teaching and Testing (Multilingual Matters, 2008). She has co-edited two special issues on the topic of interaction and language learning in a classroom context (International Journal of Educational Research, 2002; International Review of Applied Linguistics, 2009) and a special issue on the topic of pragmatic instruction (System, 2005). More recently, her publications include English and multilingualism (in press) in Chapelle, C.A. (Ed.) The Encyclopedia of Applied Linguistics; Discourse and pragmatics in SLA and Negotiated Input and Output/Interaction in The Cambridge Handbook of Second Language Acquisition. 


\section{Teachability and bilingualis m effects on learners' pragmatic knowledge}

\section{Abstract}

The present study focuses on the benefits that teaching the speech act of refusal from a discourse perspective can have on third language learners' pragmatic knowledge. Additionally, it also explores whether receptive and productive bilinguals resort to pragmalinguistic, sociopragmatic and linguistic information in different ways during the planning and execution of refusals in English. Ninety-two students of English (52 receptive bilinguals and 40 productive bilinguals of Catalan and Spanish) participated in the study, which involved a one-group pre-test/post-test design and an instructional treatment. Retrospective verbal reports were used to examine the information attended to during the pre-test and post-test role-plays, that is to say, before and after receiving instruction on refusals. Research findings showed that both receptive and productive bilinguals increased their attention and pragmalinguistic awareness of refusals in English, but the latter seemed to display a higher degree of metapragmatic awareness. In addition, productive bilinguals showed higher communicative sensitivity, mainly in the form of concern for the interlocutor's feelings, and a conversational approach that can be defined as hearer-oriented. Findings of the study add new insights on how bilingualism may influence third language pragmatic learning in instructional settings.

\section{Introduction}

The study of second language pragmatics, also referred to as interlanguage pragmatics (ILP), has prompted both cross-cultural and acquisitional studies. These studies have taken into account Leech's (1983) and Thomas's (1983) division of pragmatics into pragmalinguistics and sociopragmatics. The former refers to the resources for conveying communicative acts and interpersonal meanings, whereas the latter refers to the social perceptions underlying participants' interpretation and performance of communicative acts. Hence, ILP research has examined language users' knowledge of the means to weaken or strengthen the force of an utterance (i.e. pragmalinguistic knowledge) as well as their knowledge of the particular means that are likely to be most successful for a given situation (i.e. sociopragmatic knowledge). So far, the main focus of acquisitional ILP studies has been on learners' production and awareness of speech acts in different learning environments (Bardovi-Harlig, 2001; Bardovi-Harlig \& Dörnyei, 1998; Barron, 2003; Matsumura, 2003, 2007; Niezgoda \& 
Röver, 2001; Schauer, 2006a, 2006b; Bataller, 2010), with mixed results concerning the relationship between pragmatic knowledge and language contact environments. Furthermore, the ability to comprehend speakers' intentions has been examined in a number of studies, the results of which show that comprehension of pragmatic meaning depends on the level of indirectness encoded in the utterance, as well as learners' L2 proficiency (see for instance Taguchi, 2011). Finally, ILP research has explored the factors that potentially influence pragmatic learning. Among those factors, the teachability of speech acts has been widely examined in instructional contexts, pointing out variations in the superiority of explicit versus implicit intervention.

The study focuses on the teachability of refusals in a multilingual context. Since recent proposals for pragmatic instruction (Cohen \& Ishihara, 2009; Ishihara \& Cohen, 2010) or interventional pragmatic studies on refusals (Kondo, 2008; Alcón \& Guzman, 2010) do not include learners' multilingual background as a potential factor influencing pragmatic learning, the present investigation addresses this research gap. More specifically, the study explores whether explicit pragmatic intervention at the discourse level and learners' bilingualism (Catalan and Spanish) facilitates attention to pragmatic issues and meta-pragmatic reflection during the planning and execution of refusals in English as a third language (L3). To date, research conducted on pragmatic instruction in multilingual contexts has provided evidence that instructed bilinguals outperform monolinguals in third language speech production, more specifically in the use of requests (Safont, 2005) and request modifiers (Safont and Alcón, forthcoming). With a focus on awareness, this study addresses the issue of whether the degree of bilingualism (productive versus receptive) influences third language learners' knowledge of refusals. Dealing with third language pragmatic instruction in a particular bilingual context (Valencian Community) and exploring whether bilingualism (in this particular case receptive or productive bilingualism) makes a difference in L3 acquisition is highly relevant in ILP research, since few studies have been conducted among learners in bilingual contexts.

\section{Background research}

The role of instruction has motivated a great deal of research in the field of interlanguage pragmatics (see Jeon \& Kaya, 2006; Takahashi, 2010, for a review of the research conducted, as well as the collection of studies in Alcón \& Martínez-Flor, 2005, 2008). Until now, most pragmatic intervention research has been framed within the 
noticing hypothesis (Schmidt, 1993, 1995) and the constructs of attention and awareness have been operationalised to test whether and, if so, how instruction works for pragmatic learning. In line with the noticing hypothesis, attention is seen as a mechanism that controls access to awareness, while pragmatic awareness is defined as conscious, reflective, explicit knowledge about pragmatics. As reported by Takahashi (2010), previous interventional studies have addressed whether pragmatics is teachable, the effectiveness of implicit instruction, and learners' gains under explicit and implicit intervention. On the whole, research findings demonstrate the positive effect of explicit intervention to ensure the development of pragmalinguistic and sociopragmatic knowledge, although some forms of implicit intervention are as effective as explicit intervention for gains in pragmalinguistic knowledge.

Among the different speech acts, refusals have been the target pragmatic issue in descriptive and interventional ILP studies. Refusals belong to the category of comissives (Searle, 1976), which according to Beebe et al. (1990) consist of semantic formulas, i.e. those expressions used to perform a refusal, and adjuncts, that is, expressions which accompany a refusal but which cannot be used by themselves to perform a refusal. Semantic formulas are in turn divided into direct and indirect realisations of refusals. While direct categories include performative statements such as "I refuse" and non-performative statements like "No" or "I can't", indirect realisations are employed by the speaker to mitigate the face-threatening act. This is accomplished through the use of excuses, explanations, alternatives, avoidance, and so forth. Finally, adjuncts expressing partial agreement, gratitude, positive opinion or empathy may be used before or after the semantic formula (see Beebe et al., 1990, for a taxonomy of refusals that has been widely used or adapted in many ILP studies over the last 20 years). Gass and Houck (1999:2) also claim that the complexity of the speech act requires face-saving manoeuvres to accommodate the non-compliant nature of the act. Thus, a series of pre-refusal, main refusal and post-refusal sequences, as well as the choice of direct and indirect strategies, and adjuncts to refusals can be expected to appear in negotiated sequences in response to different speech acts such as invitations, requests, suggestions and offers.

Although refusals have been the focus of attention in a number of studies (see King \& Silver, 1993; Morrow, 1995; Kondo, 2001, 2008; Al-Issa, 2003; Kwon, 2004; AlKahtani, 2005; Keshawarz, Eslami, \& Ghahraman, 2006; Felix-Brasdefer, 2006; AlEryani, 2007; Geyang, 2007; Eslami, 2010; and the collection of studies on learning how to refuse across educational settings in Martí-Arnándiz, forthcoming), they are not 
frequently examined in interaction. Dealing with refusals at the discourse level seems to be a key issue, since, as reported by Gass and Houck (1999) and Salazar et al. (2009), refusals work as a response to an initiating act and they are co-constructed by two or more interlocutors over multiple turns. In spite of this claim, with the exception of Félix-Brasdefer (2006) and Alcón and Guzman (2010), instructional approaches dealing with English refusals have focused on semantic formulas rather than on negotiated sequences. Félix-Brasdefer (2006) presented a proposal that included three pedagogical sessions for teaching the negotiation of refusals across multiple turns in Spanish. The first one, Communicative actions and cross-cultural awareness, focused on crosscultural awareness of refusing in English and Spanish, as well as providing pragmalinguistic input on refusals. In the second one, Doing conversation analysis in the classroom, the activities are designed to examine the boundaries of a refusal sequence, the realisation of refusals across multiple turns, the initiating and ending of the refusal sequence, the strategies used to deliver the action, the taking of turns across the sequence and the constructions of roles and identities of the interlocutors during the accomplishment of the speech act. Finally, in the last session, Communicative practice and feedback, learners produced refusals by means of role-play activities and received feedback from their peers.

Following Félix-Brasdefer's suggestion (2006) of dealing with refusals at the discourse level, Alcón and Guzman (2010) carried out an interventional study to measure the effect of pragmatic instruction on foreign language learners' awareness of refusals. Participants received audiovisual pragmatic input from the series Stargate in English, which was controlled for speech act type (refusals to requests) and social distance $(+$ power and + social distance). Moreover, an instructional treatment that involved four steps was designed: identifying refusals in interaction; providing pragmalinguistic and sociopragmatic information related to the issue of directness and use of mitigation in the performance of refusals; noticing by means of awareness-raising activities; and performance of refusals in role-plays. Retrospective verbal reports were used by the authors to analyse whether instruction made a difference with regard to learners' awareness of refusals in an English as a foreign language context. Although findings from this study show the benefits of pragmatic instruction on learners' attention and awareness of pragmalinguistic and sociopragmatic issues involved in the production of refusals, the authors concluded that individual differences such as bilingualism or gender had not been considered, and suggested further research to shed 
light on whether characteristics of language learners in multilingual contexts make a difference (Todeva and Cenoz, 2009).

As a follow-up study to Alcón and Guzman (2010), the present study deals with the effect of instruction and bilingualism on learners' pragmatic awareness during the planning and execution of refusals. Considering that refusals work as a response to an initiating act, while Alcón and Guzman (2010) used scenes from the series Stargate in English and dealt with refusals to requests in a situation of + power and + social distance, the current study deals with refusals to invitations in a situation of equal distance (- power and - social distance), using scenes from the American TV show Friends, in its original version, and in its dubbed versions in Spanish and Catalan. In both studies pragmatic instruction at discourse level was conducted in intact language learning environments (translation degree courses with an average of 90 to 95 students per year) and data was collected by means of role-plays and retrospective verbal reports. Data collected in 2008-2009 were analysed in Alcón and Guzman (2010), while data collected in 2009-2010 are analysed in this paper. One relevant difference is that in this study participants are bilingual (Catalan and Spanish) learners of English as a third language and in Alcón and Guzman (2010) participants were native speakers of Spanish that were learning English as a foreign language. Research on how learners' multilingual background may influence the acquisition of additional languages is a relevant area of study in Europe, where, in addition to the co-existence of two languages within a nation-state or of national and minority language inside a country, English is often used as a lingua franca.

In fact, the advantage bilinguals have in acquiring additional languages has been pointed out by several researchers. For instance, Lambert (1990) claimed that bilingualism provides a person with a comparative and three-dimensional insight into language, a kind of stereolinguistic optic on communication that the monolingual rarely experiences. This hypothesis has been partly supported by previous research on communicative sensitivity, which may be defined as the ability to meet the listener's needs in communication exchanges and, thus, might be regarded as one feature of pragmatic competence. Genesee, Tucker and Lambert (1975) carried out an experiment with bilingual and monolingual children. Subjects described a game to two people, one of whom was blind. Results showed that bilingual speakers were more sensitive than monolinguals as regards interpersonal skills. In a similar vein, Sanz's (forthcoming) review of the effect of multilingualism on multilingual awareness points out that the higher the level of bilingualism is, the more cognitive advantages appear when 
compared to monolinguals. Bialystok (1988) and Jessner (2006) also provided evidence that higher levels of bilingualism are associated with cognitive advantages.

Although current research has dealt with the acquisition of additional languages (Cook, 1995; Cenoz, Jessner, \& Hufeisen 2001; Sanz, 2000; Safont, 2005; Pérez-Vidal et al., 2008), learners' multilingual background has not received enough attention in the field of ILP. The few studies that have been conducted focus mainly on requests (Cenoz, 2003; Safont, 2005; Safont \& Alcón, forthcoming) and report that knowledge of more than one language might affect learners' performance. Cenoz (2003) carried out a study on requests made by university learners of English in the Basque country and found that Blum-Kulka's intercultural style hypothesis could be confirmed for English language learners who had Spanish or Basque as their first language. According to the author, the advanced English language learners seemed to have developed an intercultural style that is reflected in the similarity between the performance of requests in Spanish and English and the differences from requests formulated by other native speakers of Spanish. In another study on requests, Safont (2005) examined the differences between monolinguals and bilinguals in terms of their pragmatic competence and metapragmatic awareness. Participants were 160 monolinguals (Spanish as their L1) and bilinguals (Catalan and Spanish) who were studying English as a compulsory subject at university. Results of this study showed that the bilingual learners' degree of pragmalinguistic awareness was higher than that of monolinguals and that bilinguals performed better when formulating requests. In the same vein, Safont and Alcón (forthcoming) examined the effect of bilingualism and instruction on third language learners' use of request modifiers. According to their findings, bilinguals outperform monolinguals in the number of internal and external modifiers employed both before and after having received instruction. However, with the exception of Safont (2005), studies dealing with third language pragmatic learning always focus on learners' production, thus pointing to a need for further research on how bilingualism may influence L3 learners' pragmatic knowledge.

Taking into account the need to deal with speech act instruction within the level of discourse (Kasper, 2006; Félix-Brasdefer, 2006), claims about the cognitive advantage of multilinguals (Genesee et al., 1975; Bialystok, 1988; Sanz, forthcoming) and findings pointing out the advantages of bilingualism in speech act production (Cenoz, 2003; Safont, 2005; Safont \& Alcón, forthcoming), it is our intention to explore (i) whether instruction makes a difference in learners' level of pragmatic awareness, both at the level of noticing and understanding refusals, and (ii) whether productive 
bilinguals (Catalan-Spanish) outperform receptive bilinguals in their metapragmatic awareness of English refusals. The following questions guided our study:

- Does instruction make a difference as regards learners' level of pragmatic awareness during the planning and execution of refusals?

- Does learners' degree of bilingualism influence their metapragmatic awareness of refusals before and after the instructional period?

Following the research questions stated above, two research hypotheses were formulated:

Hypothesis 1: Pedagogical intervention within the level of discourse will increase the amount of pragmatic information attended to during the planning and execution of refusals, as well as learners' understanding of refusals.

Hypothesis 2: Productive bilinguals will outperform receptive bilinguals in their metapragmatic awareness of refusals both before and after the instructional period.

\section{Method}

\subsection{Participants}

The study involved 92 students, whose ages ranged from 18 to 30 years old, the average being 22.1 years. They were all enrolled in the first year of the Degree in Translation course at one Valencian university. In the Valencian region, learners may choose between being instructed in the minority (Catalan, also referred to as Valencian) or the majority (Spanish) language during the six years of primary and the six years of secondary education. Regardless of the language of instruction in primary and secondary education, due to the similarities between Spanish and Catalan and the use of the minority language in the context where the study was conducted (i.e. the northeastern area of the Valencian region and therefore the one lying closest to Catalonia), learners are likely to become bilinguals (Catalan and Spanish), their main difference being the degree of bilingualism. For that reason, those willing to study for a degree in translation are required to take the university entrance English language test and the university Catalan/Spanish language test, where questions are also included to obtain information about the use of the majority and minority language at home and with friends. With that information, although English, Catalan and Spanish are the three working languages at university level, we observed that learners' linguistic backgrounds varied and a distinction can be made between productive bilinguals, who acquire 
Catalan as a first language, and receptive bilinguals, who acquire Catalan as a second language. All of them acquire English as a third language.

Considering the linguistic situation in the Valencian region, the 92 participants in the study (71 females and 21 males) were labelled as either receptive or productive bilinguals who were learning English as a third language. Fifty-two of the participants were "receptive bilinguals", i.e. they had been instructed in Spanish at primary and secondary school, they had acquired Catalan as a second language, and $60 \%$ of them claimed they were able to use Catalan orally, although they admitted that they did not frequently use the minority language in their everyday life. In contrast, 40 of the participants could be defined as "productive bilinguals", that is, Catalan had been the language of instruction during primary and secondary education and they made regular use of Catalan in their daily lives. Participants did not show any statistically significant differences in their level of proficiency in English, as measured by the university entrance exam they were required to pass in order to enrol on the translation degree course. Neither did participants differ to any significant extent with regard to ethnicity or academic background.

In addition, two trilingual (Spanish-Catalan-English) university lecturers (one female and one male) participated in the study. One of them focused on teaching refusals during two-hour sessions held every week for six weeks, following the pedagogical proposal mentioned below, and provided feedback on online activities. The other one observed the lessons in order to indicate (should it be the case) any bias shown by the instructor for or against the instruction procedure and conducted retrospective verbal reports on an individual basis to examine learners' awareness of refusals before and after pragmatic instruction.

\subsection{Instructional treatment}

The potential value of discourse sequences in teaching pragmatics and the need to consider learners' multilingual background is the starting point on which to develop our pedagogical proposal for teaching refusals. Moreover, the pedagogical model provides pragmatic input by means of audiovisual materials in three languages (English, Spanish and Catalan). It also combines teachers' explicit instruction with online and guided pragmatics-focused tasks.

The pedagogical model used in the present study involves four steps: Identifying refusals in interaction, Explaining the speech set acts, Noticing and understanding 
refusal sequences, and Negotiating and exploring learners' use of refusals. Examples taken from the TV series Friends were the starting point for the activities carried out during two-hour sessions held every week for six weeks. They were also used as the basis for designing online pragmatics-focused tasks on refusals. The examples were different for each of the two-hour sessions. Based on the selected excerpts from Friends, both awareness-raising activities dealing with the co-construction of refusals over turns (step 1,2,3) and self-evaluation activities for assessing learners' production of refusals (step 4) were carried out.

Step 1, Identifying refusals in interaction, was planned as a teacher-led activity in the classroom to make learners aware of the fact that refusals are to be understood in interaction and in response to an initiating act.

- Learners watch selected sequences from the series Friends, which were controlled for speech act type (refusals to invitations) and social distance (power and - social distance).

- Transcripts are provided and learners are asked to identify the beginning and end of refusal sequences.

- Teachers focus on the structure of the negotiation sequence by addressing the following questions: How many turns are the refusal sequence realised in? Is the refusal sequence realised directly or indirectly? How is it initiated? Who initiates the sequence? How do the interlocutors react to the initiating act? Who finishes the sequence?

Step 2, Explaining the speech set act, is also planned as a teacher-led activity in the classroom and it aims to provide pragmalinguistic and sociopragmatic information related to the issue of directness in the performance of refusals. The instruction focuses on:

- Explicit instruction on direct and indirect strategies, as well as on how to soften refusals in response to an invitation, taking into account the power, social distance and degree of imposition involved in the situation.

- Examples taken from the series Friends, which were controlled for speech act type (refusals to invitations) and social distance (- power and - social distance) are provided to illustrate the explicit instruction on refusals.

Step 3, Noticing and understanding refusal sequences, is designed to strengthen or potentially raise learners' explicit knowledge of refusals from a discourse approach, and 
it is planned as an online pragmatics-focused task. Learners are encouraged to download specific transcripts of the series Friends and the dubbed versions in Catalan and Spanish (see Appendix B for an example of transcripts in the three languages made available to them in a virtual classroom) and explore some of the issues presented in steps 1 and 2 on their own. The following awareness-raising questions are provided while learners read the transcripts of previously viewed sequences of the series Friends in English.

- Underline the lines where the interlocutors negotiate a refusal to an invitation. Is the refusal accepted?

- Identify the negotiation sequence of the refusal

- Circle how one of the interlocutors says "no" to an invitation

- Who initiates the sequence?

- How do the other interlocutors react to the initiating act?

- Who finishes the sequence?

- How many turns can you identify in the negotiated sequence?

- Is the refusal realised directly or indirectly?

- What language expressions are used?

- Why do participants use these expressions?

- Based on the interactional sequence, how would you describe the relationship between the interlocutors?

- Compare the performance of refusals in the transcripts with the dubbed versions of the sequences:

O Is there any difference in the language used in the Spanish, Catalan and English versions?

O Is there any difference in the way refusals are negotiated in Spanish, Catalan and English?

The answers to these questions can be downloaded for learners' self-correction. Differences in refusal sequences in the Spanish, Catalan and English versions, if any, are in italics and explained in notes.

Step 4, Negotiating and exploring refusals, gives learners the opportunity to produce refusals, taking into account the information provided in the previous teaching stages. Here role-play activities trigger refusal strategies and learners' self-evaluation of their 
recorded performance allows them to monitor their production in terms of pragmatic ability and pragmatic divergence.

Two activities are used here:

- Learners are engaged in role-play activities similar to the ones included in previously viewed audiovisual sequences, while their performance in English is recorded.

- Learners watch the audiovisual sequences and compare the audiovisual input with their oral production. Questions used in step three, Noticing and understanding refusal sequences, are used for learners' self-evaluation of their pragmatic ability.

- Learners are asked to indicate any divergence from the audiovisual input, in terms of pragmatic norms. If this was the case, they had to report whether it was due to limited grammatical ability, insufficient pragmatic ability (overgeneralisation of L3 pragmatic norm and negative transfer) or to learners' choice (resistance to using pragmatic norms).

Finally, learners' self-evaluation of their pragmatic ability and explanations of divergence from pragmatic norms are emailed to the teacher, who provides individual feedback and may use learners' comments for further action research questions.

\subsection{Data collection and analysis}

Data were collected as part of a research project conducted on the use of negotiating exhortative speech acts in instructional settings. However, for the present study we focus our analysis on refusals to invitations and on how instruction and bilingualism may influence learners' awareness of this speech act. One Erasmus student from a British university, who was a native speaker of English and was studying for a year at the university where the study was conducted, was asked to carry out a role-play with the participants in two different moments, that is to say, before and after receiving instruction on refusals (pre-test and post-test role-plays). During the pre-test, the Erasmus student explained that the Erasmus Association at the university was going to organise a party and wanted to know whether he/she could accept the invitation to come to the party. Two weeks later, the Erasmus student had to confirm whether the invitation was finally accepted during the post-test role-play. Role-plays were conducted and recorded in a seminar of the Erasmus Association with the presence of the researcher. 
The methodological decision to use role-plays with a native speaker of English was obtaining data on how our participants respond to an invitation in English in a situation of - power and - social distance. Although we acknowledge that role-plays do not trigger natural language use, they were chosen as a method of data collection for several reasons. On the one hand, participants were familiar with the situation, since they were frequently invited by the Erasmus Association to participate in their activities. The Erasmus student that participated in the role-plays was a very active member within the Association and English was the language frequently used with him. On the other hand, the use of role-plays allowed us to control the circumstances in which the invitation was formulated. As we were interested in eliciting refusals in interaction, participants were invited to a party to be held during the exam period, when the chances of the invitation being refused were high. In addition, the Erasmus student was asked to make three attempts to get the invitation accepted in order to obtain data across negotiated sequences of refusals.

In addition, retrospective verbal reports (RVRs) were used to examine participants' reflections on their own behaviour during the performance of refusals. RVRs consist in the verbalised thoughts of participants immediately after completion of the task, which provide information attended to while performing the task. To date, studies in ILP research with an interest in participants' reflections on their linguistic behaviour have employed a combination of elicitation instruments such as verbal reports and written discourse completion tasks (Robinson, 1992; Woodfield, 2010), role-plays and introspective interviews (Cohen and Olshstain, 1993; Widjaja, 1997) and role-plays and RVRs (Félix-Brasdefer, 2008; Hassall, 2008). Such studies respond to an interest in examining learners' cognitive processes during speech act performance. In line with these studies, RVRs are employed in combination with audiotaped role-plays to provide insights into third language learners' linguistic behaviour during the performance of refusals on two different occasions (pre-test and post-test role-play). Recorded pre-test and post-test role-plays were played back to each participant immediately after the performance of the role-play, and whenever they were trying to refuse an invitation the researcher paused the tape and asked what they were paying attention to and why. The sequence of data collection could be summarised as follows:

1. Pre-test recorded interview

2. Pre-test student's retrospective verbal report

3. Instructional treatment (see the pedagogical proposal above) 


\section{Post-test recorded interview}

5. Post-test student's retrospective verbal report

RVRs were coded for attention and awareness. Learners' responses to the question "what are you paying attention to?" were coded as signs of attention to linguistics (grammar, vocabulary and pronunciation) and/or pragmatics (how to say "no" to the interlocutor). Although learners also reported paying attention to other issues such as checking their agenda, not getting nervous, being surprised by the invitation, etc., these were not taken into consideration in the present study. Furthermore, learners were asked to explain why they were paying attention to those reported issues, and learners' responses were coded as signs of pragmalinguistic and sociopragmatic awareness. RVRs were coded for attention and awareness independently by two researchers. Cases of discrepancy were discussed and the following interrater agreements were obtained for attention: $96 \%$ for attention to pragmatics and $99 \%$ for attention to linguistics. Intercoder agreement for awareness was $98 \%$ for metalinguistic comments, $96 \%$ for pragmalinguistic explanations and $91 \%$ for signs of sociopragmatic knowledge. Finally, both frequency of attention paid to linguistic and pragmatic issues and frequency of explanations in relation to learners' degree of bilingualism were calculated.

The following examples illustrate the procedure used in coding learners' responses during RVRs:

\section{Example 1:}

L: I wonder whether you could come next week to our party

S2: well (2.0) I can't ((silence))

What are you paying attention to?

A word that I can't remember (attention to linguistics: vocabulary)

Why?

I do not know how to say 'ocupado' in English and I can't find a synonym (linguistic awareness)

\section{Example 2:}

$\mathrm{L}$ : you have time to decide (3.0) you...

S4: [ but ] I work in the afternoon (.) and ((silence)) 
What are you paying attention to?

I am trying to be polite, (attention to pragmatics)

Why?

It's a bad week to organise a party, I want to make up a good excuse. (pragmalinguistic awareness)

\section{Example 3:}

L: well (2.0) you know, we are going to have an Erasmus party next week. And I wonder whether you are free.

S1: yes (.) but . ((silence)) I think I can't

\section{What are you paying attention to?}

I don't know how to say no (attention to pragmatics)

Why?

I try to find a way to say no because he is a good friend and I want to be polite, but I don't want to go to that party (sociopragmatic awareness)

In our quantitative analysis of RVRs, the Kolmogorov-Smirnov tests did not confirm a normal distribution of the data, and the Wilcoxon Signed Ranks nonparametric test was used to see whether there were significant differences in learners' attention and awareness on two different occasions (pre-test and post-test). In addition, we used the non-parametric Mann-Whitney U-test to examine whether the distribution of metapragmatic awareness of English refusals was different taking into account participants' degree of bilingualism (Catalan/Spanish). RVRs were also analysed from a qualitative perspective for participants' communicative sensitivity. Role-play data were transcribed (see Appendix $\mathrm{C}$ for the transcription system used) to examine qualitative changes in learners' linguistic behaviour in two different moments, that is to say, before and after receiving instruction on refusals (pre-test and post-test role-plays).

\section{Results}

The following histograms show the changes in type of information attended to before and after receiving pragmatic instruction on refusals.

\section{INSERT FIGURES 1 AND 2 ABOUT HERE}

As illustrated in Figures 1 and 2, the percentage of participants that report paying attention to pragmatic issues in the post-test is higher than in the pre-test. In the post- 
test, all the participants report paying attention to pragmatic issues: $10.9 \%$ refer to them once, $51.1 \%$ twice and $38 \%$ three times. In contrast, in the pre-test $23.9 \%$ of participants do not refer to them and $62 \%$ only refer to them once. In relation to linguistic issues, Figures 3 and 4 show similar results in attention to linguistic issues during the pre-test and post-test RVRs. Moreover, learners do not often focus on linguistics in the pre-test and post-test, which may be explained as being due to their advanced level of English.

\section{INSERT FIGURE 3 AND 4 ABOUT HERE}

Thus, pragmatic instruction seems to move learners' attention away from grammar, vocabulary and pronunciation, and directs it more towards pragmatic issues. In order to examine whether participants' attention to pragmatic issues before and after pragmatic instruction is statistically different, we resorted to statistical tests. The KolmogorovSmirnov tests reject the null hypothesis and do not confirm a normal distribution in our data ( $p=0.000$ for the pre-test and $p=0.010$ for the post-test). Thus, non-parametric tests are used to see whether there are significant differences in learners' attention at two different moments (pre-test and post-test). Results of the Wilcoxon Signed Ranks test reveal that the differences in attention to pragmatic issues before and after instruction are large enough to be able to attribute them to random variations in scores $(\mathrm{Z}=-6.447 ; \mathrm{p}=0.000)$.

Furthermore, learners' responses to the question "Why do you say that?" were coded as signs of metalinguistic and metapragmatic awareness (including pragmalinguistic and sociopragmatic information). The total number of responses was divided into partitions and the frequency distribution of the scores was calculated as follows:

(i): Metalinguistic and metapragmatic awareness during the pre-test interviews = $(0.33 *$ Linguistics $+0.33 *$ Pragmalinguistics $+0.33 *$ Sociopragmatics $)$

(ii): Metalinguistic and metapragmatic awareness during the post-test interviews = $(0.33 *$ Linguistics $+0.33 *$ Pragmalinguistics $+0.33 *$ Sociopragmatics $)$

The percentage of responses within each partition is shown in Figure 5. As can be seen, learners' comments before receiving instruction focus on pragmalinguistic issues $(25.45 \%)$, followed by linguistics (7.9\%) and sociopragmatics (5.44\%). However, after 
receiving instruction there is an increase in the number of pragmalinguistic (36.67\%), linguistic (12.27\%) and sociopragmatic comments (12.27\%).

\section{INSERT FIGURE 5 ABOUT HERE}

In order to examine whether the differences shown in Figure 5 are significant we resorted to statistical tests. The Kolmogorov-Smirnov test rejects the null hypothesis and the Wilcoxon Signed Ranks test denotes that after receiving instruction there are no significant differences in learners' metalinguistic and sociopragmatic awareness, but the changes observed in learners' pragmalinguistic awareness are statistically significant (see Table 1). Thus, we can claim that our first hypothesis is partly confirmed. It seems that pragmatic instruction works to move learners' attention from linguistic to pragmatic issues, but it provides more gains for increasing pragmalinguistic rather than sociopragmatic knowledge.

\section{INSERT TABLE 1 ABOUT HERE}

In addition to the impact of instruction on learners' metapragmatic awareness of refusals, a qualitative analysis of participants' verbal behaviour during pre-test and posttest role-plays show changes in the way they mitigate refusals. As illustrated in Example 4, before receiving instruction participants tend to rely on "I think" as a mitigator (I think I can't, in line 4) and provide reasons for refusing the invitation ( $I$ have exams, this term is full of exams, in line 6). However, during post-test role-plays they show a wider range of linguistic resources in refusing an invitation. As shown in Example 5, they opt for the use of adjuncts to express agreement (it's great, in line 2), willingness (I would love to, in lines 6,8 and 10) or gratitude (thank you, in line 12). Finally, they also show an ability to postpone the refusal by using questions (when is it? in line 4).

\section{Example 4: Data obtained from one of the pre-test role-plays}

1. E: well (2.0) you know, we are having a party next week

2. S1: ((silence))

3. E: hmmm so, are you free Monday or

4. S1: I: I don't know. I think I can't.

5. E: come on, yes, you can you:

6. S1: [but] I have an exam (.) and this term is full of exams 
7. E: yes, I know: but this is our last week

8. S1: ((silence))

9. E: ok, see you then...

Example 5: Data obtained from one of the post-test role-plays

1. E: well, have you heard about next Erasmus welcome party?

2. L: yes, yes, that's great!

3. E: yes, will you join us <and be>

4. L: well, when is it?

5. E: next Monday

6. L: well (1.0) I would love to attend, but:

7. E: yes, <I think is difficult but:

8. L: [I] would love to (.) but

9. E: [ well] , I hope you can make it

10. L: yes, yes, I would love to and I guess I'll will

11. E: [that] would be great:

12. L: but I'll let you know, thank you

13. E: no worries, See you

With regard to Hypothesis 2, our intention was to examine whether the degree of bilingualism (Catalan-Spanish) might influence learners' metapragmatic awareness of English refusals before and after the instructional treatment. With that aim in mind, learners' metapragmatic explanations were classified into two types - pragmalinguistic and sociopragmatic - and compared in relation to learners' degree of bilingualism in two different moments: during the pre-test and post-test RVRs. Learners' degree of bilingualism was coded as either level 1 or 2 . Those coded as level 1 could be defined as receptive bilinguals (52 of the participants). They had not received previous instruction in Catalan during primary and secondary education, and they did not frequently use the minority language in everyday interaction. In contrast, those coded as level 2 could be defined as productive bilinguals (40 of the participants). They had been educated in Catalan, which was their language of instruction at school, and they made regular use of Catalan in their daily lives.

As can be seen in Table 2, the mean of pragmalinguistic and sociopragmatic explanations provided by productive bilinguals (level 2) is higher than the explanations provided by receptive bilinguals (level 1).

\section{INSERT TABLE 2 ABOUT HERE}

In order to establish more accurately whether this difference is related to the degree of bilingualism, the Mann-Whitney statistical test was used and learners' explanations 
of their linguistic behaviour were compared. Results of the Mann-Whitney statistical test revealed that after receiving pragmatic instruction there seem to be statistically significant differences that can be explained in terms of learners' degree of bilingualism. Thus, Hypothesis 2, which claimed that productive bilinguals would outperform receptive bilinguals in their metapragmatic awareness of English refusals before and after the instructional period, is partly supported. Our results reveal that before receiving instruction on refusals both monolingual and bilingual learners of English give reasons for their language use that are not statistically significant ( $\mathrm{p}=0.064$ for pragmalinguistics and $\mathrm{p}=0.119$ for sociopragmatics). However, after pragmatic instruction the difference is statistically significant $(p=0.029$ for pragmalinguistics and $\mathrm{p}=0.029$ for sociopragmatics), which indicates that instruction works better for productive bilinguals than for receptive ones.

In line with Safont and Alcón (forthcoming), we can claim that productive bilinguals seem to gain more from pragmatic instruction than receptive bilinguals. However, before receiving pragmatic instruction, the current study does not reveal significant differences for knowledge of refusals by productive and receptive bilinguals, while in Safont and Alcón (forthcoming) bilinguals outperformed monolinguals in the use of request modifiers in English, both before and after pragmatic instruction. Whether or not bilingualism and instruction has an impact on third language pragmatic learning is an issue to be tested in further experimental research. In fact, a qualitative analysis of RVRs shows that productive bilinguals display a higher degree of pragmatic awareness and higher communicative sensitivity in the pre-test. This is illustrated in the following extracts from role-plays (Examples 6 and 7). While in Example 6 receptive bilinguals deal with refusals from a speaker-oriented approach and concern for delivering a message, in Example 7 productive bilinguals show evidence of higher communicative sensitivity, mainly in the form of concern for their interlocutors' feelings, and follow a hearer-oriented communicative approach.

Example 6. RVR obtained from the following pre-test role-play with a receptive bilingual:

E: well, <you know> we are going to hold a party and we'd like to invite you to come (.)

S: that's great! thank you.

L: so:: I wonder whether you could come next week to our first meeting

S: ((silence))

L: it will be great if you could come 
S: $\quad$ well, next week is not possible (.) I have I'll have my first exam:

RVR: What are you paying attention to?

I do not know how to say no

RVR: Why?

I was thinking if I could and I realised that I couldn't but it was hard for me to find the words to say that, but finally I did. I knew how to say it but I have a doubt with the verb and I remember that exams were until end of the month.

Example 7. RVR obtained from the following pre-test role-play with a productive bilingual:

E: Would you like to join us?

$\mathrm{S} 1: \quad(($ silence $))$

E: If you can it would be great

S1: Yes:: You are right. I think I have exams:::

RVR: What are you paying attention to?

I was trying to find a way or an excuse

RVR: Why?

He is cool and I did not want to be rude or show that I was not interested in what they are doing, because that is not true. Besides, he is working as a kind of teacher and I wanted to be polite.

Taking into account the impact of bilingualism on higher communicative sensitivity, it is necessary to test whether bilinguals' higher communicative sensitivity is a factor that may influence gains from pragmatic instruction. Thus, following insights from this exploratory study, further experimental research on the role of instruction and bilingualism in L3 pragmatic learning is needed across different populations and educational settings.

\section{Discussion}

How can the findings related to our two hypotheses be explained in view of previous research? In relation to Hypothesis 1, previous research conducted on ILP interventional studies and, more specifically on refusals, provides evidence of the effect of pragmatic intervention on learners' gains on pragmalinguistic and sociopragmatic 
knowledge (see Takahashi, 2010, for a review of ILP interventional studies and MartíArnándiz, forthcoming, for studies on refusals in instructional contexts). However, in the present study the interventional treatment results in gains for increasing pragmalinguistic rather than sociopragmatic knowledge. We are aware that situational variation and learners' linguistic background are issues to be considered in pragmaticsfocused instruction. Thus, it is necessary to acknowledge that the eliciting act and conditions under which data were collected may have influenced our findings. This may explain why in Alcón and Guzman (2010) instruction works as a way to increase pragmalinguistic and sociopragmatic knowledge, while in the present study only pragmalinguistic knowledge seems to improve. The authors use the same pedagogical proposal to teach the speech act of refusals, but in their study pragmatic input is provided by means of scenes from the series Stargate (a science fiction series), which were controlled for speech act type (refusals to requests) and social distance (+ power and + social distance). In the present study, however, pragmatic input is provided using excerpts from the series Friends (a sitcom series) and the focus is on refusals to invitations in a situation of - power and - social distance. In addition, whereas Alcón and Guzman (2010) focused on teaching refusals in English as a foreign language, in the present study Catalan, English and Spanish are the target languages of instruction.

Another issue to be considered when comparing results of the present study with those from previous research is that most ILP research studies assess what is attended to by means of post-test tasks, such as discourse evaluation tests, while in this study we have used the combination of role-play data and RVRs as a method to measure learners' pragmatic knowledge of refusals. In other words, in line with Félix-Brasdefer (2008), Hassall (2008) and Woodfield (2010), first-person accounts, despite their subjectivity, have been used to assess whether learners are able to consciously attend to and understand the pragmatic information provided during the instruction. This might have influenced research outcomes, opening up a further research question as to whether first-person accounts of attending to pragmatic information are similar to what we could obtain from other elicitation instruments, such as discourse evaluation tasks, which are widely used when analysing language learners' pragmatic awareness (Martínez-Flor and Alcón, 2007). To answer this question, and as suggested by Hama \& Leow (2010), further research is needed to explore the effect of pragmatic instruction, employing both online and offline measurement tasks. Similarly, the interactive effects of eliciting tasks and pragmatic instruction need to be further addressed (Fukuya \& Martínez-Flor, 2008).

With regard to research findings related to Hypothesis 2, previous research has 
revealed that bilingual learners show advantages when learning a third language (Bialystok, 1988; Sanz, 2000) and more specifically when they learn pragmatics (Cenoz, 2003; Safont, 2005; Safont \& Alcón, forthcoming). Results from the present study support previous research and add new insights on how the degree of bilingualism may influence pragmatic gains. By using RVRs we can offer one explanation of why the degree of bilingualism may influence the acquisition of English as a third language. In the present study, before receiving instruction on refusals no significant difference was found between receptive and productive bilinguals. On the contrary, we found evidence that productive bilinguals, who showed higher communicative sensitivity, outperformed receptive bilinguals in pragmalinguistic awareness after the instructional period. Thus, one possible explanation for productive bilinguals' gains after pragmatic instruction may be found in their communicative sensitivity. Following Lambert's hypothesis (1990:212), another possible explanation might be that productive bilinguals are better able to store information, or that the contrast between linguistic systems that productive bilinguals continually make aids them in reporting pragmatic knowledge. It is also possible that productive bilinguals may already have control over intended meaning and social variables affecting language use, and thus all they had to do was gain control over refusal strategies and the use of adjuncts to refusals. In contrast, receptive bilinguals may require further attention to first control intended meaning and then map form and context appropriately. These are, of course, tentative hypotheses. To test these hypotheses further research is also needed to address how learners process pragmatic input concurrently (see Leow, 1997; Rosa \& Leow, 2004 and Leow et al., 2011)

\section{Conclusions, limitations and further research}

The present study examines the benefits that teaching the speech act of refusal from a discourse perspective has on L3 learners' pragmatic knowledge. Retrospective verbal reports are used to examine the impact of instruction on attention and awareness of refusals, and to explore whether receptive and productive bilingual learners resort to pragmalinguistic, sociopragmatic and linguistic information in different ways during the planning and execution of refusals. Research findings show that teaching refusals at the discourse level increases L3 learners' pragmalinguistic awareness of refusals, regardless of their degree of bilingualism. In contrast, productive bilinguals outperform receptive bilinguals in metapragmatic awareness after receiving instruction on refusals.

Two research gaps are addressed in the present study. On the one hand, most ILP 
studies dealing with the role of instruction to draw learners' attention to pragmatics assess what is attended to by means of post-test tasks such as discourse evaluation tests. In the present study, following cognitive psychology, first-person accounts after exposure, despite their subjectivity, have been used to assess whether learners are able to consciously attend to the pragmatic information provided during the instruction. On the other hand, studies dealing with bilingualism and third language pragmatic learning in the Valencian region have provided evidence on the effect of bilingualism and instruction on L3 speech production (Safont and Alcón, forthcoming) and they have started to offer details about how children learn pragmatics (Safont, 2011). By focusing on awareness rather than production, and dealing with a population of young adults, the present study provides further evidence on how bilingual education may enhance third language pragmatic learning.

Some limitations are to be considered. First, we are aware that the scripted language of Friends is not natural language, but we made use of it because, in instructional contexts, audiovisual material can provide learners with pragmatic input, which in this study were refusals to invitations (see also Quaglio, 2009, for further information on a corpus analysis of the scripted language of Friends). Moreover, the pedagogical model is based on the analysis of refusals performed in the American sitcom Friends in its original and dubbed versions (Spanish and Catalan). As pointed out by one of the reviewers, it is true that cultural issues are not always taken into account in the dubbed versions. Nevertheless, in the particular language-learning context where the study was conducted, the use of audiovisual material in English, Catalan and Spanish provides learners with opportunities to be exposed to these languages in contextual situations, showing how linguistic resources (pragmalinguistics) vary according to contextual factors (sociopragmatics). Second, we acknowledge that if we had included a control group, it would have strengthened the claim that changes in the pre-test and post-test are more likely, due to the instruction that was involved, or we could have tested whether the control group makes progress over time. However, the study was conducted in a regular language-learning environment and adding a control group was not feasible. Following Rose and Kasper (2001), the present study deals with the teachability of refusals and adopts a pre-test/post-test design to examine whether refusals are teachable to a particular group of learners that receive instruction on refusals. Third, individual variability may have influenced research outcomes. We have not considered learners' gender, socioeconomic status, attitudes or emotions (Dewaele, 2007), although, among other variables, these may provide us with further insights into their role in 
interventional pragmatic studies. Furthermore, results of the study are to be understood in relation to one speech act in one situation, namely refusing an invitation in a situation of - power and - social distance. Further evidence is needed from different speech acts and situational variations, as well as future research is needed to investigate the role of awareness at the construction and reconstruction stages of pragmatic learning.

Finally, following the superiority of bilingual learners after receiving pragmatic instruction, further research is also needed to address whether receiving compulsory education in a bilingual mode influences the acquisition of pragmatics by third language learners across educational contexts. In this study it seems that the more formal bilingual instruction one has had (that is to say, the productive bilinguals), the more benefits one may get from pragmatics-focused instruction that invites meta-pragmatic reflection. Since we acknowledge that participants are translation students and are likely to have heightened linguistic meta-awareness because of the studies they are doing, other research with different populations will be appreciated.

\section{References}

Alcón, Eva \& Alicia Martínez-Flor (eds.). 2005. Pragmatics in instructed language learning. (Special issue) System, 33 (3)

Alcón, Eva \& Alicia Martínez-Flor (eds.). 2008. Investigating Pragmatics in Foreign Language Learning, Teaching and Testing. Clevedon: Multilingual Matters.

Alcón, Eva \& Josep Guzman. 2010. The effect of instruction on learners' pragmatic awareness: A focus on refusals. International Journal of English Studies 10 (1). 65-80.

Al-Eryani, Abdulah A. 2007. Refusal strategies by Yemeni EFL learners. The Asian EFL Journal 9 (2). 19-34.

Al-Issa, Ahmad. 2003. Sociocultural transfer in L2 speech behaviors: evidence and motivating factors. International Journal of Intercultural Relations 27(5). 581-601.

Al-Kahtani, Saad A. 2005. Refusals in three different cultures: A speech act theoretically-based cross-cultural study. Language and Translation 18. 35-57.

Bardovi-Harlig, Kathleen. 2001. Evaluating the empirical evidence: Grounds for instruction in pragmatics? In Kenneth R. Rose \& Gabriele Kasper (eds.), Pragmatics in language teaching, 13-32. Cambridge: Cambridge University Press.

Bardovi-Harlig, Kathleen \& Zoltan Dörnyei. 1998. Do language learners recognize pragmatic violations? Pragmatic versus grammatical awareness in instructed L2 learning. TESOL Quarterly 32 (2). 233-262. 
Barron, Anne. 2003. Acquisition in interlanguage pragmatics. Learning how to do things with words in a study abroad context. Pragmatics and Beyond New Series 108. Amsterdam/Philadelphia: Benjamins.

Bataller, Rebeca. 2010. Making a request for a service in Spanish: pragmatic development in the study abroad setting. Foreign Language Annals 43 (1).160-175.

Beebe, Leslie. Tomoko Takahashi \& Robin Uliss-Weltz. 1990. Pragmatic transfer in ESL refusals. In Robin C. Scarcella, Elaine S. Anderson \& Stephen Krashen (eds.), Developing Communicative Competence in Second Language, 55-73. New York: Newbury House.

Bialystok, Ellen. 1988. Levels of bilingualism and levels of linguistic awareness. Developmental Psychology 24 (4). 560-567.

Cenoz, Jasone. 2003. The intercultural style hypothesis: L1 and L2 interaction in requesting behaviour. In Vivian Cook (ed.), Effects of the second language on the first, 62-80. Clevedon: Multilingual Matters.

Cenoz, Jasone, Ulrike Jessner \& Britta Hufeisen (eds). 2001. Cross-Linguistic Influence in Third Language Acquisition: Psycholinguistic Perspectives. Clevedon: Multilingual Matters.

Cohen, Andrew D. \& Elite Olshtain. 1993. The production of speech acts by EFL learners. TESOL Quarterly 27(1). 33-56

Cohen, Andrew \& Noriko Ishihara. 2009. New Insights into Teaching Pragmatics in the ESL/EFL Classroom. Paper presented at the 43rd Annual TESOL Convention, Denver, $\mathrm{CO}$.

Cook, Vivian. 1995. Multi-competence and the learning of many languages. Language, Culture and Curriculum 8 (2). 93-98.

Dewaele, Jean Marc. 2007. Context and L2 users' pragmatic development. In Zhu Hua, Paul Seedhouse, Li Wei \& Vivian Cook (eds.), Language learning and teaching as social inter-action, 162-183. Basingstoke: Palgrave-Macmillan.

Eslami, Zohreh. 2010. Refusals: How to develop appropriate refusal strategies. In Alicia Martínez-Flor \& Esther Usó-Juan (eds.), Speech act performance. Theoretical, empirical and methodological issues, 217-236. Amsterdam: John Benjamins.

Felix-Brasdefer, César, J. 2006. Teaching the negotiation of multi-turn speech acts: using conversation-analytic tools to teach pragmatics in the FL classroom. In Katheleen Bardovi-Harlig, César J. Felix-Brasdefer \& Alwiya S. Omar (eds.), Pragmatics 
language learning, 11, 165-198. Honolulu: University of Hawai'i, National Foreign Language Resource Center.

Félix-Brasdefer, César, J. 2008 Perceptions of refusals to invitations: Exploring the minds of foreign language learners. Language Awareness 17(13). 195-211.

Fukuya, Yoshinori \& Alicia Martínez-Flor. 2008. The interactive effects of pragmaticeliciting tasks and pragmatic instruction. Foreign Language Annals, 41(3). 478-500.

Gass, Susan \& Nöel Houck. 1999. Interlanguage refusals: A cross-cultural study of Japanese-English. New York: Mouton de Gruyter.

Genesee, Fred, Richard Tucker \& Wallace Lambert. 1975. Communication skills in bilingual children. Child Development, 46 (4).1010-1014.

Geyang, Zhou. 2007. A pilot study on refusal to suggestions in English by Japanese and Chinese EFL learners. Bulletin of the Graduate School of Education. Part II 56, 155163. Hiroshima University.

Hama, Mika \& Ronald, R. Leow. 2010. Learning without awareness revisited: Extending Williams (2005). Studies in Second Language Acquisition 32 (3). 465-491.

Hassall, Tim. 2008. Pragmatic performance: What are learners thinking? In Eva Alcón \& Alicia Martínez-Flor (eds.), Investigating Pragmatics in Foreign Language Learning, Teaching and Testing, 72-93. Bristol, Avon: Multilingual Matters.

Ishihara, Noriko \& Andrew Cohen. 2010. Teaching and learning pragmatics. Where language and culture meet. Harlow: Longman

Jeon, Eun. H. \& Tadayoshi Kaya. 2006. Effects of L2 instruction on interlanguage pragmatic development. In John M. Norris \& Lourdes Ortega (eds.), Synthesizing research on language learning and teaching, 165-211. Amsterdam: John Benjamins.

Jessner, Ulrike. 2006. Linguistic awareness in multilinguals. Edinburgh: Edinburgh University Press.

Kasper, Gabriele. 2006. Speech acts in interaction: Towards discursive pragmatics. In Katheleen Bardovi-Harlig, César Felix-Brasdefer \& Alwiya S. Omar (eds.), Pragmatics and language learning, 11, 281-314. Honolulu: University of Hawai'i, National Foreign Language Resource Center.

Keshawarz, Mohamed, H., Zohreh R. Eslami \& Vahid Ghahraman. 2006. Pragmatic transfer and Iranian EFL refusals: A cross-cultural perspective of Persian English. In Katheleen Bardovi-Harlig, César Felix-Brasdefer \& Alwiya S. Omar (eds.), Pragmatics 
and language learning 11, 359-401. Honolulu: University of Hawai'i, National Foreign Language Resource Center.

King, Kendala \& Rita Silver. 1993. Sticking points: Effect of instruction on NNS refusal strategies. Working Papers in Educational Linguistics 9 (1). 47-82.

Kondo, Sachiko. 2001. Instructional effects on pragmatic development: Refusal by Japanese EFL learners. Publications of Akenohoshi Women's Junior College 19 (3). 3251.

Kondo, Sachiko. 2008. Effects on pragmatic development through awareness-raising instruction: Refusals by Japanese EFL learners. In Eva Alcón and Alicia Martínez-Flor, (eds.), Investigating pragmatics in foreign language learning, teaching and testing, 153-177. Clevedon: Multilingual Matters.

Kwon, Jihyun. 2004. Expressing refusals in Korean and American English. Multilingua 23 (4), 339-364.

Lambert, Wallace E. 1990. Persistent issues in bilingualism. In Birgit Harley, Patick Allen, Jim Cummins \& Merill Swain (eds.), The Development of second language proficiency, 201-220. Cambridge: Cambridge University Press.

Leech, Geoffrey. 1983. The principles of pragmatics. London: Longman

Leow, Ronald P., Ellen Johnson \& Germán Zárate-Sández. 2011. Getting a grip on the slippery construct of awareness: Toward a finer-grained methodological perspective. In Cristina Sanz \& Ronald P. Leow (eds.), Implicit and explicit language learning: conditions, processes and knowledge in SLA and bilingualism, 61-72. Washington, D.C: Georgetown University Press.

Leow, Ronald, P. 1997. Attention, awareness, and foreign language behaviour. Language Learning 47 (3). 467-505.

Martí-Arnándiz, Otilia (forthcoming). Refusals in instructional contexts and beyond. Amsterdam: Rodopi.

Martínez-Flor, Alicia \& Eva Alcón. 2007. Developing pragmatic awareness of suggestions in the EFL classroom: A focus on instructional effects. Canadian Journal of Applied Linguistics 10(1). 47-76.

Matsumura, Shoichi. 2003. Modelling the relationships among interlanguage pragmatic development, L2 proficiency, and exposure to L2. Applied Linguistics 24 (4). 465-491. 
Matsumura, Shoichi. 2007. Exploring the after effects of study abroad on interlanguage pragmatic development. Intercultural Pragmatics 4 (2). 167-192.

Niezgoda, Kimberly \& Carsten Röver. 2001. Pragmatic and grammatical awareness: a function of the learning environment? In Kenneth R. Rose \& Gabriele Kasper (eds.), Pragmatics in Language Teaching, 63-79. Cambridge: Cambridge University Press.

Pérez-Vidal, Carmen, María Juan-Garau \& Aurora Bel (eds.). 2008. A portrait of the Young in the new multilingual Spain. Clevedon: Multilingual Matters

Quaglio, Paulo. 2009 Television dialogue: The sitcom Friends vs natural conversation. Amsterdam: John Benjamins.

Robinson, M.A. 1992. Introspective methodology in interlanguage pragmatics research. In Gabriele Kasper (ed.), Pragmatics of Japanese as a native and target language, 2782. Second Language Teaching \& Curriculum Center Technical Report \#3. Honolulu, HI: University of Hawai'i Press.

Rosa, Elena. M. \& Ronald P. Leow. 2004. Awareness, different learning conditions, and L2 development. Applied Psycholinguistics 25 (2). 269-292.

Rose, Kenneth R. \& Gabriele Kasper (eds.). 2001. Pragmatics in language teaching. Cambridge: Cambridge University Press.

Safont, María Pilar. 2005. Third Language Learners. Pragmatic Production and Awareness. Clevedon: Multilingual Matters.

Safont, María Pilar. 2011. Early requestive development in consecutive third language learning. International Journal of Multilingualism.

Safont, María Pilar \& Eva Alcón. Forthcoming. Teachability of request act peripherical modification devices in third language learning contexts. In Maria EconomidouKogetsidis \& Helen Woodfield (eds), Interlanguage request modification. Pragmatics and beyond new series. Amsterdam: John Benjamins.

Salazar, Patricia, María Pilar Safont \& Victoria Codina. (2009) Refusal strategies: a proposal from a sociopragmatic approach. Revista electronica de Lingüística Aplicada 8: $139-150$

Sanz, Cristina. 2000. Bilingual education enhances third language acquis ition: Evidence from Catalonia. Applied Psycholinguistics 21 (1). 23-44.

Sanz, Cristina. Forthcoming. Multilingualism and metalinguistic awareness. In Carol. A. Chapelle (ed.), The Encyclopedia of applied linguistics. Oxford, UK: Wiley and Sons 
Schauer, Gila. A. 2006a. Pragmatic awareness in ESL and EFL contexts: Contrast and development. Language Learning 56 (2). 269-318.

Schauer, Gila.A. 2006b. The development of ESL learners' pragmatic competence: A longitudinal investigation of awareness and production. In Katheleen Bardovi-Harlig, César Felix-Brasdefer \& Alwiya, S. Omar (eds.), Pragmatics and language learning 11, 135-164. Honolulu: University of Hawai'i, National Foreign Language Resource Center. Schmidt, Richard. 1993. Consciousness, learning and interlanguage pragmatics. In Gabriel Kasper \& S. Blum-Kulka (eds.), Interlanguage Pragmatics, 21-42. New York: Oxford University Press.

Schmidt, Richard. 1995. Consciousness and foreign language learning: A tutorial on the role of attention and awareness in learning. In Richard Schmidt (ed.), Attention and awareness in foreign language learning, 1-63. Honolulu: University of Hawai'i, Second Language Teaching and Curriculum Center.

Searle, John. R. 1976. The classification of illocutionary acts. Language in Society 5 (1). 1-24.

Taguchi, Naoko. 2011. The effect of L2 proficiency and study-abroad experience on pragmatic comprehension. Language Learning 61 (3). 904-939.

Takahashi, Satomi. 2010. The effect of pragmatic instruction on speech act performance. In Alicia Martínez-Flor and Esther Usó-Juan (eds.), Speech act performance. Theoretical, empirical and methodological issues, 127-144. Amsterdam: John Benjamins.

Thomas, Jenny. 1995. Meaning in interaction. An introduction to pragmatics. New York: Longman

Todeva Elka \& Jasone Cenoz. 2009. Multiple perspectives on multilingualism. Personal narratives and researchers' perspectives. Berlin: Mouton de Gruyter.

Widjaja, C.1997. A study of date refusal: Taiwanese females vs. American females. University of Hawaii Working paper in ESL 15: 1-43.

Woodfield, Helen. 2010. What lies beneath? Verbal report in interlanguage requests in English. Multilingua 29 (1). 1-27. 


\section{Appendix A}

An example of a transcript from the series Friends available in the virtual classroom.

Season 5 Episode 7. The One Where Ross Moves In

[Scene: Monica and Rachel's, Rachel is opening the door.]

Rachel: Oh, hi Danny.

Danny: Hey guys, I just uh, wanted to invite you to the party tomorrow night.

Monica: Oh, thanks! We'll try to stop by.

Rachel: Uh, actually, I think I'm gonna be busy.

Monica: You are?

Rachel: Yeah! Remember I got that uh, gala.

Danny: Yeah, what's the gala for?

Rachel: It's a uh, regatta gala.

Danny: Really! You-you sail?

Rachel: No-no, but I support it.

Danny: Okay, (To Monica) hope I see you tomorrow night.

Monica: Okay.

Danny: Take care. (Leaves.)

Rachel: Okay. (Closes the door.) Walked right into that one didn't he?

Monica: What one? You wanted him to invite you to the party and he did it!

Rachel: Yeah, but he waited until the last minute! So if I said yes, he would know I had nothing better to do than wait around for an invitation to his stupid party. I said, "No!" Which puts me right back in the driver seat.

Monica: Great. So the ball is in his court?

Rachel: Ball? There is no ball. 


\section{Appendix B}

An example of a transcript from the series Friends and the dubbed version in Spanish and Catalan available in the virtual classroom.

Season 8 Episode 22. The One Where Rachel Is Late

\begin{tabular}{|c|c|c|c|}
\hline Character & English & Spanish & Catalan \\
\hline Ross & $\begin{array}{l}\text { Hey! What } \\
\text { are you guys } \\
\text { looking at? }\end{array}$ & $\begin{array}{l}\text { Hola! ¿Qué } \\
\text { estáis } \\
\text { mirando? }\end{array}$ & $\begin{array}{l}\text { Hola! Què és això } \\
\text { que mireu? }\end{array}$ \\
\hline Joey & $\begin{array}{l}\text { Oh, it's a } \\
\text { poster for } \\
\text { that World } \\
\text { War I movie } \\
\text { that I'm in, } \\
\text { check it out. }\end{array}$ & $\begin{array}{l}\text { Es un poster } \\
\text { de mi peli } \\
\text { sobre la } \\
\text { primera } \\
\text { Guerra } \\
\text { mundial. } \\
\text { Fíjate! }\end{array}$ & $\begin{array}{l}\text { Un pòster de la } \\
\text { meua pel·lícula } \\
\text { de la primera } \\
\text { guerra mundial. } \\
\text { Què et pareix? }\end{array}$ \\
\hline Ross & $\begin{array}{l}\text { Yeah? Wow! } \\
\text { It looks } \\
\text { really } \\
\text { violent! }\end{array}$ & $\begin{array}{l}\text { Caray, parece } \\
\text { superviolenta }\end{array}$ & $\begin{array}{l}\text { Vaja! Pareix molt } \\
\text { violenta }\end{array}$ \\
\hline Joey & $\begin{array}{l}\text { Uh-huh! I } \\
\text { know. I'm } \\
\text { coming soon } \\
\text { to a theater } \\
\text { near you! I'm } \\
\text { in THX! I'm } \\
\text { unsuitable } \\
\text { for children! }\end{array}$ & $\begin{array}{l}\text { He, he, lo sé. } \\
\text { Estaré } \\
\text { próximamente } \\
\text { en un cine del } \\
\text { barrio, en } \\
\text { dolby-thx. No } \\
\text { soy apto para } \\
\text { niños. }\end{array}$ & $\begin{array}{l}\text { Sí, sí. I tant. } \\
\text { L’estrenaran ja } \\
\text { molt prompte. És } \\
\text { en THX. I és per } \\
\text { a majors. }\end{array}$ \\
\hline Ross & $\begin{array}{l}\text { Now I cannot } \\
\text { wait to see } \\
\text { this. }\end{array}$ & $\begin{array}{l}\text { Tío, estoy } \\
\text { ansioso por } \\
\text { verla. }\end{array}$ & $\begin{array}{l}\text { Ondia, estic } \\
\text { ansiós per vore- } \\
\text { la. }\end{array}$ \\
\hline Joey & $\begin{array}{l}\text { Yeah, yeah, } \\
\text { it's already } \\
\text { generating } \\
\text { Oscar buzz. }\end{array}$ & $\begin{array}{l}\text { Sí, sí ya está } \\
\text { generando } \\
\text { rumores de } \\
\text { Óscar }\end{array}$ & $\begin{array}{l}\text { Sí, sí, ja corren } \\
\text { els rumors de } \\
\text { l'Òscar }\end{array}$ \\
\hline Phoebe & I started that! & $\begin{array}{l}\text { Los empecé } \\
\text { yo. }\end{array}$ & $\begin{array}{l}\text { Jo els he } \\
\text { començat. }\end{array}$ \\
\hline Joey & $\begin{array}{l}\text { I thought I } \\
\text { did! Oh hey } \\
\text { guess what? } \\
\text { The premiere } \\
\text { is next week } \\
\text { and you're }\end{array}$ & $\begin{array}{l}\text { Creía que } \\
\text { había sido yo. } \\
\text { Ah! Oye, por } \\
\text { cierto. Acabo } \\
\text { de hablar con } \\
\text { mi agente, el }\end{array}$ & $\begin{array}{l}\text { Creia que havia } \\
\text { sigut jo. Ah! } \\
\text { Sabeu què? } \\
\text { L'estrena és la } \\
\text { setmana que ve i }\end{array}$ \\
\hline
\end{tabular}




\begin{tabular}{|c|c|c|c|}
\hline & all invited! & $\begin{array}{l}\text { estreno es la } \\
\text { semana que } \\
\text { viene y estáis } \\
\text { invitados. }\end{array}$ & esteu convidats. \\
\hline Monica & $\begin{array}{l}\text { Are we } \\
\text { gonna take a } \\
\text { limo? }\end{array}$ & $\begin{array}{l}\text { ¿Iremos en } \\
\text { limusina? }\end{array}$ & $\begin{array}{l}\text { Anirem en } \\
\text { limusina? }\end{array}$ \\
\hline Joey & $\begin{array}{l}\text { Sure! Why } \\
\text { not?! }\end{array}$ & $\begin{array}{l}\text { Claro, ¿por } \\
\text { què no? }\end{array}$ & Sí, clar que sí \\
\hline Monica & $\begin{array}{l}\text { Oh I love } \\
\text { taking limos } \\
\text { when nobody } \\
\text { died! }\end{array}$ & $\begin{array}{l}\text { Me encanta ir } \\
\text { en limusina } \\
\text { cuando no ha } \\
\text { muerto nadie }\end{array}$ & $\begin{array}{l}\text { Ui! M'encanta } \\
\text { anar en limusina } \\
\text { si no s'ha mort } \\
\text { ningú }\end{array}$ \\
\hline Rachel & $\begin{array}{l}\text { Well } \\
\text { obviously I } \\
\text { won't be able } \\
\text { to come, for } \\
\text { those of you } \\
\text { who haven't } \\
\text { checked their } \\
\text { calendars } \\
\text { today is my } \\
\text { due date. } \\
\text { Well y'know, } \\
\text { I just want to } \\
\text { take a } \\
\text { moment and } \\
\text { thank you } \\
\text { guys for how } \\
\text { great you've } \\
\text { been during } \\
\text { this time. I } \\
\text { really } \\
\text { couldn't have } \\
\text { done it } \\
\text { without you. } \\
\text { And I have } \\
\text { loved these } \\
\text { last nine } \\
\text { months! And } \\
\text { even though I } \\
\text { am so } \\
\text { looking } \\
\text { forward to } \\
\text { the next part, } \\
\text { I am really } \\
\text { gonna miss } \\
\text { being }\end{array}$ & $\begin{array}{l}\text { Es evidente } \\
\text { que yo no } \\
\text { podré ir. Para } \\
\text { los que que no } \\
\text { habéis echado } \\
\text { un vistazo al } \\
\text { calendario hoy } \\
\text { salgo de } \\
\text { cuentas. No } \\
\text { quiero dejar } \\
\text { escapar esta } \\
\text { oportunidad } \\
\text { para daros las } \\
\text { gracias por lo } \\
\text { fantásticos } \\
\text { que habéis } \\
\text { sido conmigo. } \\
\text { No podría } \\
\text { haberlo hecho } \\
\text { sin vosotros. } \\
\text { Y me han } \\
\text { encantado los } \\
\text { últimos nueve } \\
\text { meses. Y } \\
\text { aunque tengo } \\
\text { ganas de que } \\
\text { llegue la } \\
\text { siguiente fase, } \\
\text { voy a echar de } \\
\text { menos estar } \\
\text { embarazada. }\end{array}$ & $\begin{array}{l}\text { Bé, } \\
\text { lamentablement } \\
\text { no podré anar, per } \\
\text { a aquells que no } \\
\text { han mirat el } \\
\text { calendari, hui isc } \\
\text { de comptes. Ara } \\
\text { voldria aprofitar } \\
\text { el moment per } \\
\text { agrair-vos el } \\
\text { vostre suport } \\
\text { durant tot el } \\
\text { temps. No } \\
\text { haguera pogut } \\
\text { aconseguir-ho } \\
\text { sense vosaltres. I } \\
\text { he gaudit d'estos } \\
\text { nous mesos. I } \\
\text { encara que tinc } \\
\text { ganes d'arribar a } \\
\text { la següent fase, } \\
\text { trobaré a faltar } \\
\text { l'embaràs. }\end{array}$ \\
\hline
\end{tabular}




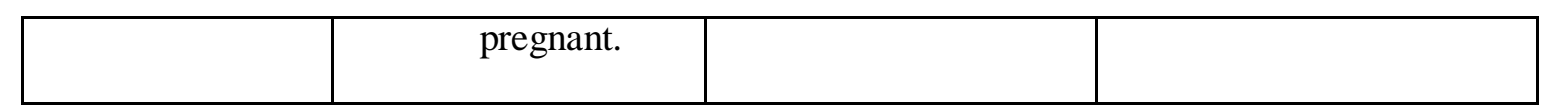




\section{Appendix C}

TRANSCRIPTIONS CONVENTIONS (Adapted from Nguyen \& Kasper, 2009).

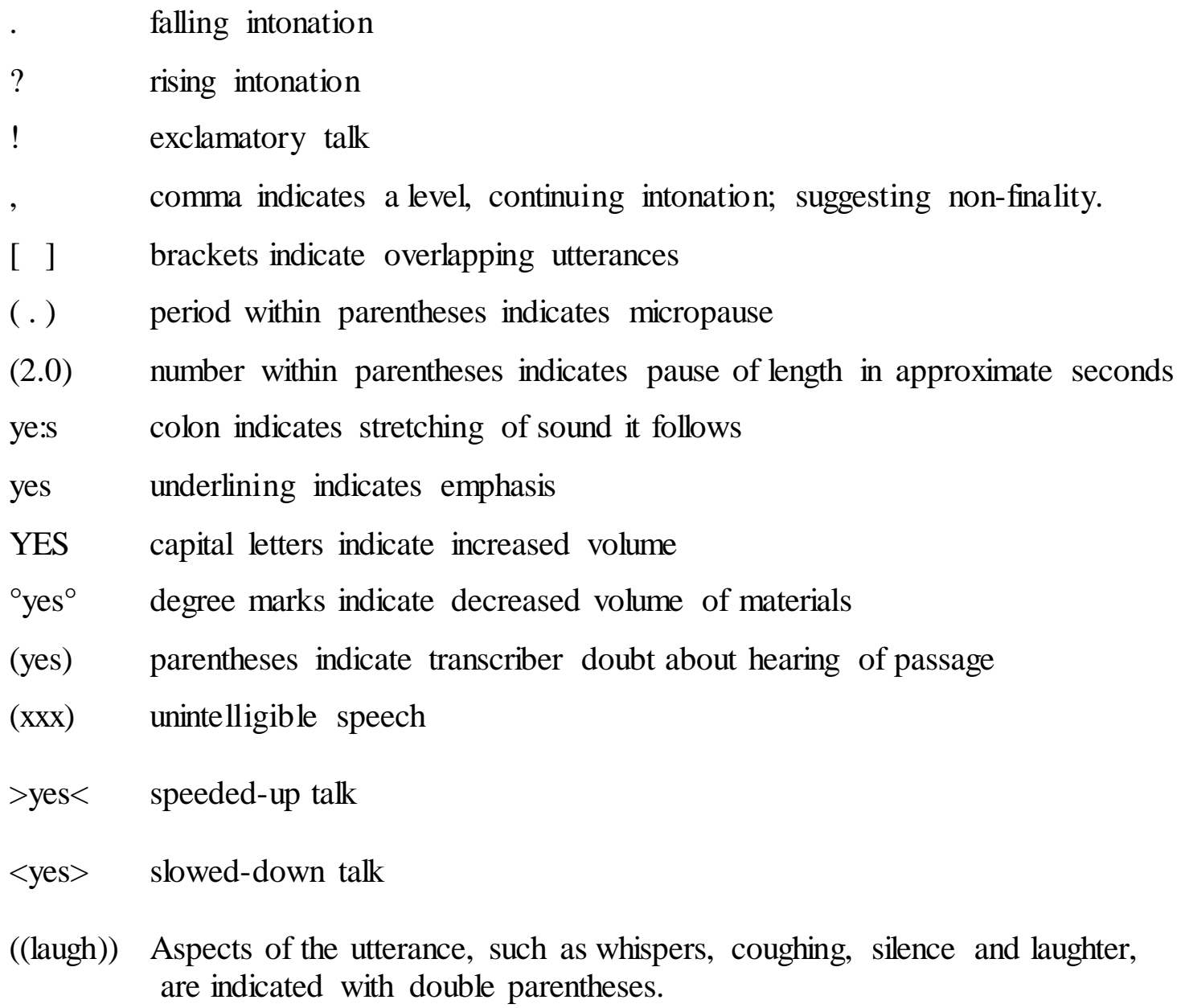




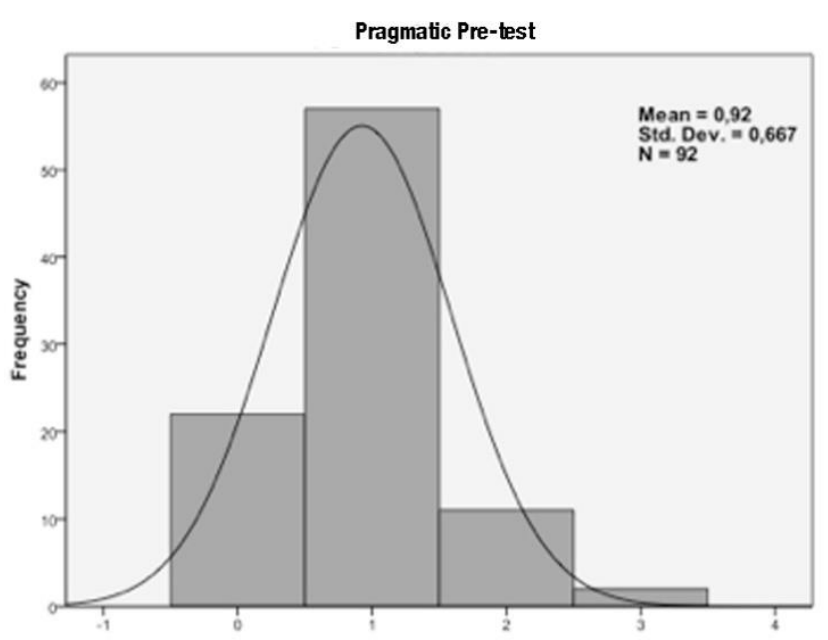

Figure 1: Attention to pragmatic issues in the pre-test

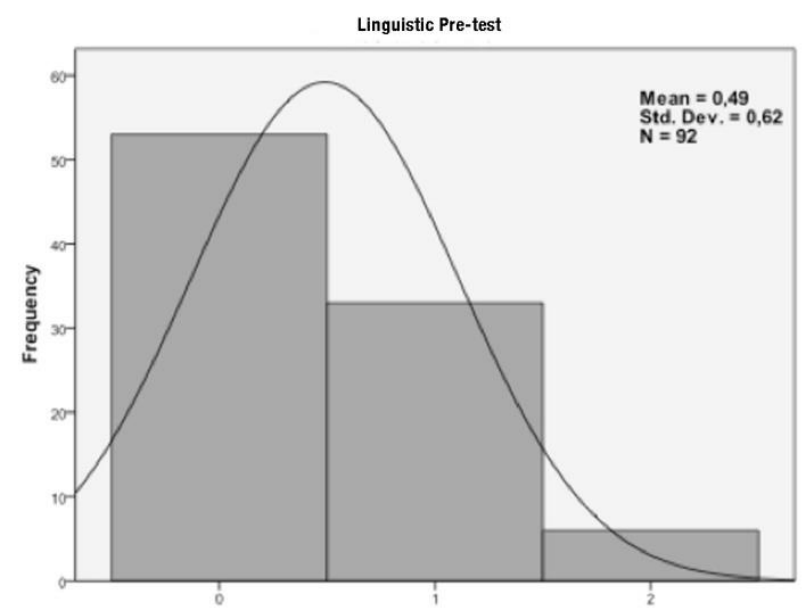

Figure 3: Attention to linguistic issues in the pre-test

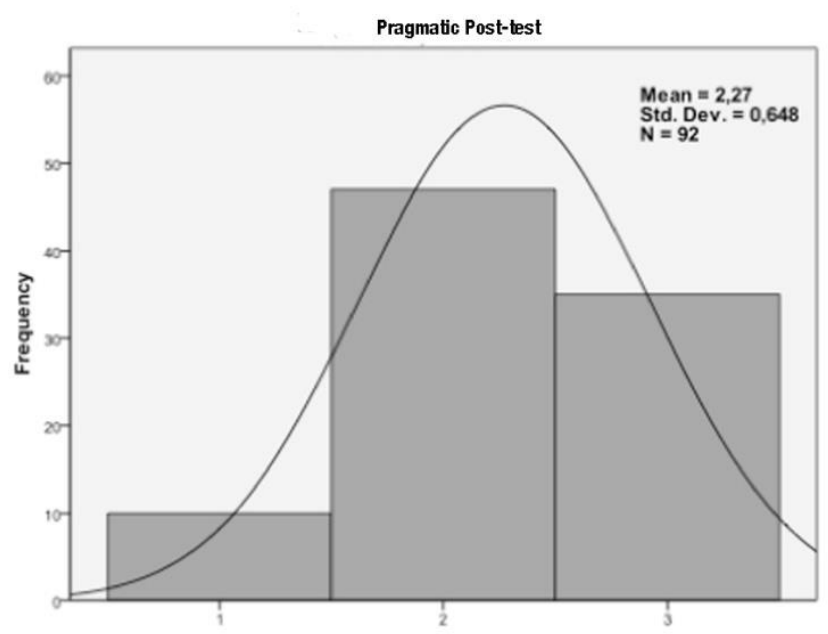

Figure 2: Attention to pragmatic issues in the post-test

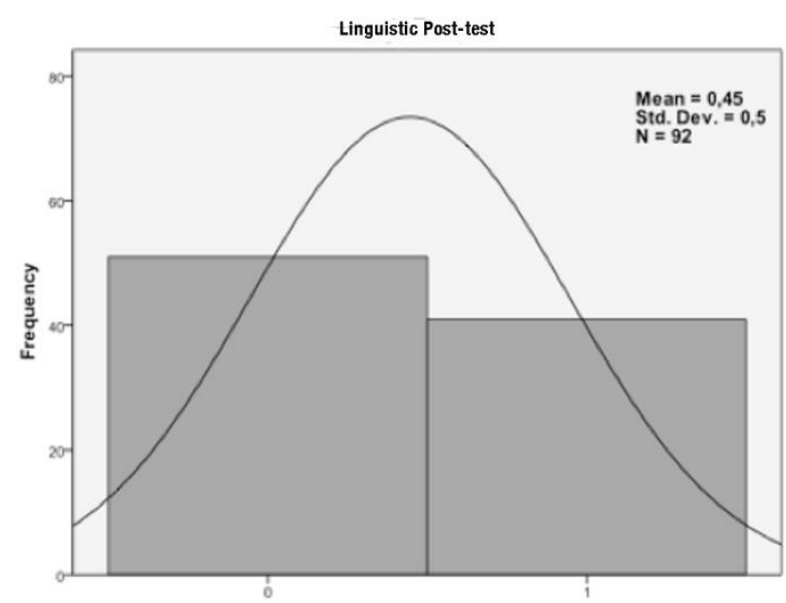

Figure 4: Attention to linguistic issues in the post-test 


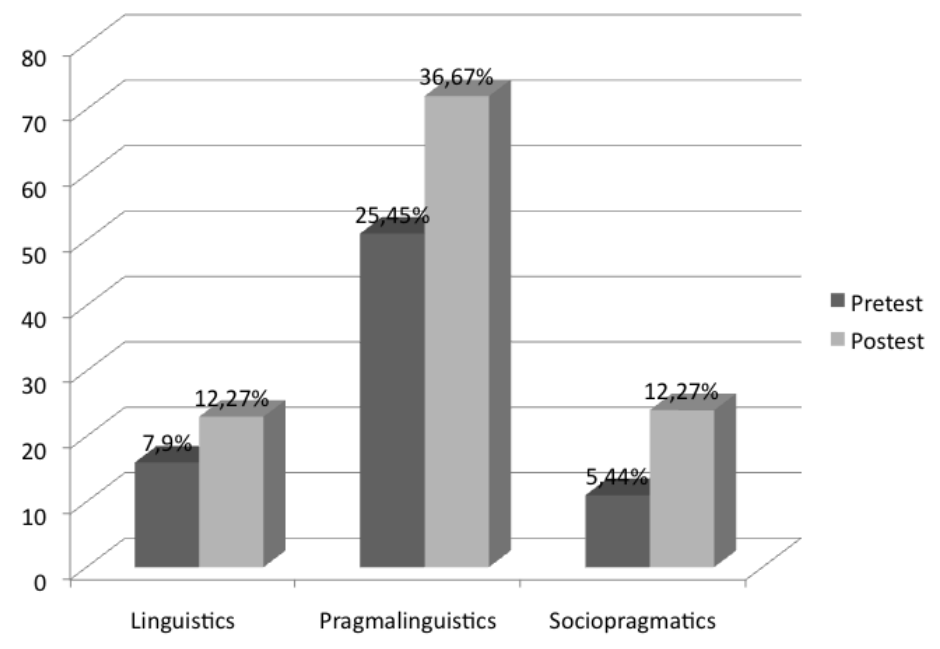

Figure 5: Percentage of linguistic, pragmalinguistic and sociopragmatic explanations provided by learners during the pre-test and the post-test retrospective reports 


\begin{tabular}{|c|c|c|c|c|c|}
\hline & $\mathrm{N}$ & Mean & Std. Deviation & Z & $\begin{array}{l}\text { Asymp. Sig. } \\
\text { (2-tailed) }\end{array}$ \\
\hline PE-Linguistics & 92 & .49 & .620 & \multirow{4}{*}{$-.7140^{\mathrm{a}}$} & \multirow{3}{*}{.475} \\
\hline & & & & & \\
\hline PO-Linguistics & 92 & .45 & .500 & & \\
\hline PE-Pragmalinguistics & 92 & .99 & .667 & & \multirow{3}{*}{.000} \\
\hline & & & & \multirow[t]{2}{*}{$-7.623^{\mathrm{a}}$} & \\
\hline PO-Pragmalinguistics & 92 & 2.00 & .648 & & \\
\hline PE-Sociopragmatics & 92 & .34 & .475 & \multirow{3}{*}{$-2.673^{b}$} & \multirow{3}{*}{.008} \\
\hline & & & & & \\
\hline PO-Sociopragmatics & 92 & .45 & .500 & & \\
\hline
\end{tabular}

a. Based on negative ranks

b. Wilcoxon Signed Ranks Test

Table 1. Differences in linguistic, pragmatic and sociopragmatic explanations of participants' verbal be haviour in the pre-test and post-test retrospective verbal reports 


\begin{tabular}{|l|l|l|l|l|}
\hline Multilingualism & $\begin{array}{l}\text { Pre-test } \\
\text { Pragmalinguistics }\end{array}$ & $\begin{array}{l}\text { Post-test } \\
\text { Pragmalinguistics }\end{array}$ & $\begin{array}{l}\text { Pre-test } \\
\text { Sociopragmatics }\end{array}$ & $\begin{array}{l}\text { Post-test } \\
\text { Sociopragmatics }\end{array}$ \\
\hline $\mathbf{1}$ & .40 & .35 & .27 & .25 \\
$\mathrm{~N}$ & 52 & 52 & 52 & 52 \\
\hline Std. Deviation & .634 & .480 & .448 & .450 \\
\hline Mean & .60 & .58 & .43 & .52 \\
N & 40 & 40 & 40 & .501 \\
\hline Std. Deviation & .591 & .501 & .501 & .45 \\
Mean & .49 & .45 & .34 & .52 \\
\hline N & 92 & .52 & .475 & .500 \\
\hline
\end{tabular}

Table 2. Differences in pragmalinguistic and sociopragmatic explanations in relation to learners' degree of multilingualism 